\title{
First confirmed case of lead poisoning in the endangered Egyptian Vulture (Neophron percnopterus) in the Balkans
}

\section{Anastasios Bounas, ${ }^{1, *}$, Maria Ganoti ${ }^{2}$, Eirini Giannakaki ${ }^{2}$, Achilleas Akrivos $^{3}$, Dimitris Vavylis ${ }^{1}$, Irene Zorrilla ${ }^{4}$ and Victoria Saravia ${ }^{1}$}

\author{
${ }^{1}$ Hellenic Ornithological Society, Themistokleous 80, 10681, Athens, Greece \\ ${ }^{2}$ Anima Wildlife Rescue Center, Menelaou 134, 17676, Athens, Greece \\ ${ }^{3}$ Hellenic Veterinary Laboratories S.A., Paiania 19002, Athens, Greece \\ ${ }^{4}$ Environmental and Water Agency of Andalusia, Division of Integrated Environmental \\ Quality. Regional Ministry of Environment and Spatial Planning, Center for Analysis \\ and Diagnosis of Wildlife - CAD, Avda. Lope de Vega, 9, Málaga 29010, Spain
}

*Corresponding author: tasosbounas@gmail.com

http://dx.doi.org/10.4314/vulnew.v70i1.2

\section{Introduction}

Incidents of lead poisoning in birds have been continuously reported from all around the world (Fisher $e t$ al. 2006). There are different sources that can cause lead poisoning such as contaminated soil that can be found in the vicinity of mines and industrial plants (Garcia-Fernandez et al. 1995, Beyer et al. 2000) or sludge from sewage treatment facilities that is disposed in agricultural land (Pattee \& Pain 1995) but the most common source causing lead toxicosis in birds is the ingestion of lead ammunition commonly used for hunting (Miller et al. 2002, Fisher et al. 2006). Birds of prey are one of the main groups affected by exposure to lead impacting several threatened species such as the White-tailed Eagle (Haliaeetus albicilla) and the Spanish Imperial Eagle (Aquila adalberti) (Mateo 2009). Vultures are particularly susceptible to lead ingestion from carcasses with embedded lead shot due to their scavenging nature and several cases 
of poisoned vultures have been recorded mainly in Spain (Mateo et al. 1997, Gangoso et al. 2009, Rodriguez-Ramos et al. 2009). Here we report the case of an Egyptian Vulture (Neophron percnopterus) found in Greece with high levels of lead in the blood. This represents, to the authors' knowledge, the first confirmed lead poisoning incident in the species eastern-European range.

A five years old Egyptian Vulture was found alive on 30 April 2014 in Western Macedonia region $\left(40^{\circ} 24^{\prime} \mathrm{N}\right.$, $\left.21^{\circ} 30^{\prime} \mathrm{E}\right)$, Greece, by two forest wardens working in the Kozani Forestry Service. The bird originated from Bulgaria, where it had been ringed as a chick in the nest in 2010 by the Bulgarian Society for the Protection of Birds / Birdlife Bulgaria. It was initially admitted to the Wildlife First Aid Center in Kastoria (North-western Greece) and then moved to the more specialized ANIMA Wildlife Rescue Center in Athens (http://www.wild-anima.gr). The vulture weighed $1900 \mathrm{~g}$ [normal weight for adult is 1600-2200 $\mathrm{g}$ (Del Hoyo et al. 1994)] and showed extreme head and leg weakness, anorexia, dehydration and green faeces. There was not any apparent sign of trauma. We suspected the ingestion of a poisonous substance and we administered immediately intramuscular ultra-carbon charcoal plus $1 \mathrm{ml}$ Dexamethasone as well as intramuscular cortisone and antibiotics in order to stabilize the animal before subsequent analyses; after that, every day we administered a total of $150 \mathrm{ml}$ of fluids (Ringer's solution intravenously, Ringer's solution together with dextrose and vitamin B subcutaneously, and chicken broth with dextrose orally). Blood analysis was conducted in the Hellenic Veterinary Laboratories in Athens and the results (Table 1) showed an abnormal level of both Aspartate Aminotransferase (SGOTAST) and Creatinine Phosphokinase (CPK) with serum values of 1298 IU/L and 3451 IU/L respectively. We also detected slight increase in the number of lymphocytes in the blood (i.e. lymphocytosis) that probably was a response to the stress of handling and treatment. Blood lead levels were extremely high, measuring $3210 \mu \mathrm{g} / \mathrm{L}$ (values of more than $1000 \mu \mathrm{g} / \mathrm{L}$ are considered toxic; Polo et al. 1992, Fransson 1996) thus confirming lead poisoning. X-rays revealed the absence of shots embedded in the vulture's body but since lead is rapidly dissolved due to the low $\mathrm{PH}$ in raptor stomachs, it can be absorbed and cause sudden illness or death (Gill \& Langelier 1994). Thus 
it is possible that the vulture might cases that involve raptors having have fed on the carcass of an animal ingested lead shots (Kenntner et al. killed by lead shots. Such cases of 2005). lead poisoning represent the $24 \%$ of

Table 1: Results of biochemical analysis carried out on a lead poisoned adult Egyptian Vulture (Neophron percnopterus) when it was admitted to ANIMA wildlife rescue center (3 May 2014) and after 10-day treatment (13 May 2014).

\begin{tabular}{|c|c|c|c|}
\hline \multirow{2}{*}{ Analyses } & \multicolumn{2}{|c|}{ Results } & \multirow{2}{*}{ Reference values ${ }^{1,2}$} \\
\hline & 3rd May 2014 & 13th May 2014 & \\
\hline $\begin{array}{l}\text { Creatinine } \\
\text { Phosphokinase (CPK) } \\
\text { (IU/L) }\end{array}$ & 3451 & 2509 & $346-464$ \\
\hline $\begin{array}{l}\text { Aspartate } \\
\text { Aminotranferase } \\
\text { (SGOT-AST) (IU/L) }\end{array}$ & 1298 & 674 & $58.9-77.1$ \\
\hline Protein $(\mathrm{g} / \mathrm{dL})$ & 4.3 & 5.4 & $3.1-4.8$ \\
\hline Haematocrit (\%) & 51 & 56 & $38-48$ \\
\hline Lead $(\mu \mathrm{g} / \mathrm{L})$ & 3210 & & $\begin{array}{c}\text { <200: Background } \\
\text { 200-1000:Subclinical } \\
\text { >1000: Toxic }\end{array}$ \\
\hline
\end{tabular}

${ }^{1}$ : Polo et al. 1992

2: Fransson 1996 
Once the vulture had recovered after 10-day treatment it was tagged with a satellite transmitter and released back in the area where it had been found. The bird eventually left this area and moved to north-eastern Greece, more than $350 \mathrm{~km}$ away.

The Egyptian Vulture is rapidly declining throughout its global range and is thus listed as "Endangered" in the IUCN Red List of Threatened Species (BirdLife 2014) with populations in Europe declining around $50 \%$ the last 50 years (Iñigo et al. 2008). Specifically in the Balkans the situation is worse, as the species has suffered a steep decrease of $80 \%$ in the last 30 years, at an estimated rate of $6 \%$ per year in the last decade (Velevski et al. 2015). This is thought to be due to a combination of several known threats such as poisoning (Skartsi et al. 2014), electrocution (Angelov et al. 2011) and direct persecution in their wintering grounds (Arkumarev et al. 2014). Lead poisoning is an additional threat that may be overlooked. The establishment of facilities that can perform toxicological analysis of vultures is needed in the Balkans in order to assess the threat, since any mortality that can be avoided especially in such a small population - less than 70 pairs left in the whole of the
Balkans (Velevski et al. 2015) - is of key conservation importance. Lead shots and bullet fragments have been recognized as main sources of lead contamination in birds (Kendall et al. 1996 but see Pikula et al. 2013) and some countries in Europe have developed regulations against the use of lead shot for hunting (Mateo 2009); in Greece the use of lead shot for hunting is only banned in wetlands which helps some but not all species vulnerable to lead poisoning. Moreover, the hunting season in Greece ends each year on 28 February, so in the case we here report the lead ingested by the Egyptian Vulture most probably originated from an illegal hunting event. It is important that governments in the Balkans enforce any existing laws banning the use of lead ammunition, oblige hunters to comply with the hunting periods and educate hunting associations in order to restrict the effects of lead ammunition in the environment. Hunters can also contribute in this direction by shooting only the prey they can retrieve and by removing all the remains of hunted animals from the countryside. In addition, the construction of networks of small supplementary feeding stations in the areas where the last pairs of Egyptian Vulture survive could help mitigate 
the problem in the short-term and at the same time also promote the conservation of other vulture species and opportunistic scavengers. Other key conservation measures suggested, although with results in the longer-term, are a complete lead ammunition ban combined with the promotion of non-toxic alternatives (e.g. steel) thus preventing endangered species such as the Egyptian Vulture suffering the additional burden of lead toxicosis, which can seriously impact the population as a whole.

\section{Acknowledgements}

We are very thankful to the forest wardens from Kozani Forestry Service, NGO Arcturos First Aid team and Nikos Panagiotopoulos from the Wildlife First Aid Center in Kastoria for their immediate response and coordination. Stoyan C. Nikolov, Konstantina Ntemiri and three anonymous reviewers provided constructive comments in a previous draft of this paper. The work was financially supported by the LIFE+ project "The Return of the Neophron" (LIFE10 NAT/BG/000152) funded by the European Union and co-funded by the AG Leventis Foundation.

\section{References}

Angelov, I., Hashim, I. \& Oppel, S. 2011. Persistent electrocution mortality of Egyptian Vultures Neophron percnopterus over 28 years in East Africa. Bird Conservation International 23: 1-6.

Arkumarev, V., Dobrev, V., Abebe, Y. D., Popgeorgiev, G. \& Nikolov, S. C. 2014. Congregations of wintering Egyptian Vultures Neophron percnopterus in Afar, Ethiopia: present status and implications for conservation. Ostrich 85: 139-145.

Beyer, W. N., Audet, D. J., Heinz, G. H., Hoffman, D. J. \& Day, D. 2000. Relation of waterfowl poisoning to sediment lead concentrations in the Coeur d'Alene River Basin. Ecotoxicology 9: 207-218. 
BirdLife International. 2014. Species factsheet: Neophron percnopterus.

Downloaded from http://www.birdlife.org on 29/10/15

Del Hoyo, J., Elliot, A. A. \& Sargatal, J. 1994. Handbook of the Birds of the World, Vol. 2. New World Vultures to Guineafowl. Ediciones Lynx, Barcelona, Spain.

Fisher, I. J., Pain, D. J. \& Thomas, V. G. 2006. A review of lead poisoning from ammunition sources in terrestrial birds. Biological Conservation 131: 421-432.

Franson, J. C. 1996. Interpretation of tissue lead residues in birds other than waterfowl. In: Beyer, W. N., Heinz, G. H. \& Redmon-Norwood, A. W. (Eds). Environmental Contaminants in Wildlife: Interpreting Tissue Concentrations, pp. 265-279. Lewis Publishers, Boca Raton.

Gangoso, L., Alvarez-Lloret, P., Rodríguez-Navarro A. A., Mateo, R., Hiraldo, F. \& Donazar, J. A. 2009. Long-term effects of lead poisoning on bone mineralization in vultures exposed to ammunition sources. Environmental Pollution 157: 569-574.

García-Fernández, A. J., Sánchez-García, J. A., Jiménez-Montalbán, P. \& Luna, A. 1995. Lead and cadmium in wild birds in southeastern Spain. Environmental Toxicology and Chemistry 14: 2049-2058.

Gill, C. E. \& Langelier, K. M. 1994. Acute lead poisoning in a bald eagle secondary to bullet ingestion. The Canadian Veterinary Journal 35: 303 304.

Iñigo, A., Barov, B., Orhun, C. \& Gallo-Orsi, U. 2008. Action plan for the Egyptian Vulture Neophron percnopterus in the European Union. BirdLife International and European Commission, Brussels

Kendall, R. J., Lacker, T. E., Bunck, C., Daniel, B., Driver, C., Grue, C. E., Leighton, F., Stansley, W., Watanabe, P. G. \& Whitworth, M. 1996. An ecological risk assessment of lead shot exposure in non- waterfowl avian species: Upland game birds and raptors. Environmental Toxicology and Chemistry 15: 4-20.

Kenntner, N., Tataruch, F. \& Krone, O. 2005. Risk assessment of environmental contaminants in white-tailed sea eagles (Haliaeetus 
albicilla) from Germany. In: Pohlmeyer, K. (Ed.). Extended Abstracts of the XXVIIth Congress of the International Union of Game Biologists, pp. 125-127. Hannover, Germany.

Mateo, R. 2009. Lead poisoning in wild birds in Europe and the regulations adopted by different countries. In: Watson, R. T., Fuller, M., Pokras, M. \& Hunt, W. G. (Eds). Ingestion of lead from spent ammunition: implications for wildlife and humans, pp. 71-98. The Peregrine Fund, Boise.

Mateo, R., Molina, R., Grifols, J. \& Guitart, R. 1997. Lead poisoning in a free ranging griffon vulture (Gyps fulvus). Veterinary Record 140: 47-48.

Miller, M. J. R., Wayland, M. E. \& Bortolotti, G. R. 2002. Lead exposure and poisoning in diurnal raptors: a global perspective. In: Yosef, R. M., Miller, M. L. \& Pepler, D. (Eds). Raptors in the New Millennium, Proceedings of the Joint Meeting of the Raptor Research Foundation and The World Working Group on Birds of Prey and Owls, pp. 224-245. Eilat, Israel.

Pattee, O. H. \& Pain, D. J. 2003. Lead in the environment. In: Hoffman, D. J., Rattner, B. A., Burton, G. A., Jr. \& Cairns, J., Jr. (Eds). Handbook of ecotoxicology, pp. 373-408. CRC Press, Boca Raton.

Pikula, J., Hajkova, P., Bandouchova, H., Bednarova, I., Adam, V., Beklova, M., Kral, J., Ondracek, K., Osickova, J. \& Pohanka, M. 2013. Lead toxicosis of captive vultures: case description and responses to chelation therapy. BMC Veterinary Research 9: 11.

Polo, F., Celdran, J., Peinado, V., Viscor, G. \& Palomeque, J. 1992. Hematological values for four species of birds of prey. Condor 94: 10071013.

Rodriguez-Ramos, J., Gutierrez, V., Höfle, U., Mateo, R., Monsalve, L., Crespo, E. \& Blanco, J. M. 2009. Lead poisoning in wild birds in Europe and the regulations adopted by different countries. Extended abstract In: Watson, R. T., Fuller, M., Pokras, M. \& Hunt, W. G. (Eds). Ingestion of lead from spent ammunition: implications for wildlife and humans, pp. 7198. The Peregrine Fund, Boise.

Skartsi, T., Dobrev, V., Oppel, S., Kafetzis, A., Kret, E., Karampatsa, R., Saravia. V., Bounas, A., Vavylis, D., Sidiropoulos, L., Arkumarev, V., 
Dyulgerova, S. \& Nikolov, S. C. 2014. Assessment of the illegal use of poison in the Egyptian vulture project sites in Greece and Bulgaria for the period 2003-2012. Technical Report, WWF Greece, Athens.

Velevski, M., Nikolov, S. C., Hallmann, B., Dobrev, V., Sidiropoulos, L., Saravia, V., Tsiakiris, R., Arkumarev, V., Galanaki, A., Kominos, T., Stara, K., Kret, E., Grubač, B., Lisičanec, E., Kastritis, T., Vavylis, D., Topi, M., Hoxha, B. \& Oppel, S. 2015. Population decline and range contraction of the Egyptian Vulture Neophron percnopterus on the Balkan Peninsula. Bird Conservation International 25: 440-450.

$* * * * * *$ 